Jakub Zamana ${ }^{1}$ Janusz Jartyś ${ }^{2}$

\title{
POLITICAL, SOCIAL AND LEGAL TRANSFORMATION OF HUMAN RIGHTS RELATING TO NON-HETERONORMATIVE MEN IN GERMANY
}

Keywords: Germany, human rights, Paragraph 175, European Union

\begin{abstract}
In the article below the authors analyse the political, social and legal revaluations of human rights relating to non-heteronormative men in Germany, from the rise of the German Empire (Zweites Reich) till contemporary times. What is important is not only a change in the mentality of the German society throughout the last hundred years, but also the fact that the legal system of the Federal Republic of Germany (Deutsche Bundesrepublik, BRD) was using a provision that had been created during the Nazi dictatorship and applied it to its own citizens. The authors of this article demonstrate that the social changes in the BRD in the second half of the 20th century were much faster than the amendment of the legal system; what is more, the BRD has not faced its Nazi past, failing to atone to homosexual men who had been persecuted on the basis of a Nazi legal provision, inherited and applied by a democratic state.
\end{abstract}

\section{INTRODUCTION}

The moment it was created on 7 September 1949, the Federal Republic of Germany (Deutsche Bundesrepublik, BRD) was an idiosyncratic legal subject of the international law. Its establishment was the result of the

1 Jakub Zamana, University of Warsaw, Faculty of Political Science and International Studies, zamana85@wp.pl.

2 Janusz Jartyś, University of Szczecin, Faculty of Humanities, Institute of Political Science and European Studies, janujar.eu@gmail.com. 
international situation at the time and the decision of the western states occupying the territory of the Third Reich after its defeat. This newly established legal subject of the international law was unusual due to the fact that the Basic Law of the Federal Republic of Germany was created before the proclamation of the state itself (Grugensetz 2004:12). Konrad Adenauer as the Chancellor signed the Basic Law almost four months before the first session of the recently elected Bundestag took place. Thus, the newly established West Germany had to both create the new, democratic structures and to face the Nazi past inherited from the Third Reich in political, social and cultural aspects. The critical analysis applied further in this article demonstrates that this task was not of a primary importance for the Federal Republic of Germany, and that in this particular respect, the Nazi legislation and all its derivatives continued to be applied in Germany for further 45 years. Moreover, what needs to be examined as well is the change in the mentality of German society and the attitude of German political parties to non-heterosexual persons throughout the existence of the BRD within the boundaries established on 7 September 1949, till 3 October 1990, when the German Democratic Republic (Deutsche Demokratische Republik, DDR), which had been established on 7 October 1949 from the Soviet occupation zone, was taken over by the BRD as five new lands (Vertrag...). In this respect, a genetic, and institutional and legal methods are applied to illustrate the transformation of the provisions of the state law, with some aspects of the theory of social change and theory of europeanization applied as well, due to the fact that the Federal Republic of Germany is one of the founding states of the European Communities and the European Union, and attach a lot of importance to the implementation of the European law and European values.

\section{THE RIGHTS OF NON-HETERONORMATIVE MEN FROM THE GERMAN EMPIRE TO THE FEDERAL REPUBLIC OF GERMANY}

In questions of decent behaviour, the Federal Republic of Germany inherited its legislation from the Third Reich. The provisions of Paragraph 175 applied already in the German Empire since 21 January 1872 (Sig- 
mund, 2015, p. 153) and stipulated a prison sentence and loss of honour for inappropriate sexual behaviour, which included homosexual relations between men and zoophilia, and this legal situation outlived both the German Empire and the Weimar Republic, where there was no political imperative to remove this provision of the law (Verfolgung, 2017, p. 2). However, it should be stressed that, in spite of these legal provisions, the 1920s in the capital of Germany were characterized by a large dose of liberalism as a result of liberal and leftist politics of the times. Berlin of this period was a cosmopolitan city with many gay and lesbian clubs, nightclubs and cabarets. There were also many secret locations, where both heterosexuals and homosexuals could admire vocal performances (SPDqueer...). A large number of homosexual men and women did not hide their sexual orientation, but were quite open about it, or even flaunted it (Sigmund, 2015, p.154). It may be concluded that Berlin was then an enclave of social liberalism in Germany. It does not mean, however, that the provisions of Paragraph 175 were not applied in practice in Germany. In 1928,804 people were sentenced according to this law, which is 686 more than in 1918 (Dippold, Leisteter, 2013, p.3), and in 1932, which is the last year before Adolf Hitler's rise to power, 801 people were prosecuted for homosexual acts (Sigmund, 2015, p.167).

When NSDAP came to power in Germany and appointed Adolf Hitler the Chancellor of Germany in 1933, the plan to remove homosexual behaviours from the public space started to be realized. All associations of homosexuals were dissolved, and all magazines and newspapers linked to homosexual communities, including the famous Der Eigene, were banned. These actions of the Nazi power were a fulfilment of promises made by the Nazis in the last years of the Weimer Republic. Already in 1928 during a session of Reichstag, the spokesman of NSDAP stated: "whoever thinks of love between a woman and a woman, or a man and a man, is our enemy" (Sigmund, 2015, p.155). In the light of these events, a novelization of Paragraph 175 made in 1935 is not surprising; it made the existing criteria even stricter. Clause a) was added to existing provisions of this law, according to which a suspicion of immoral behaviour, including sexual relations between men, was enough to charge (Geschichte...). In the Third Reich homosexuality became and unwanted 
element, a disease or a deviance, in contradiction to the ambition to create "a new, Aryan nation". The modified law allowed the Nazi authorities not only to pinpoint another enemy of the nation and the government, but also constituted an important weapon in the political conflict with the opposition. It has also been used in the conflicts among the national socialists, which is exemplified by the so-called Night of the Long Knives on 28 June 1934, during which the leaders of the Sturmabteilung (SA) were executed, among them Ernst Röhm, known for his homosexual inclinations. Admittedly, the official reason for the execution of the SA leaders were the alleged plans of a coup, although on 30 June 1934 Adolf Hitler used one of his metaphors when he said: "Führer gave an order to mercilessly remove this ulcer; and in the future he will not allow individuals with deviant inclinations to burden and compromise millions of decent people" (Biedroń, 2012, p.27).

Polish diplomats from the Polish Embassy in Berlin also reported the use of Paragraph 175 in the political fight with the Prussian Junkers after the Night of the Long Knives. Representatives of aristocracy were removed from their positions on the basis of Paragraph 175. An important illustration of this fact was the use of Sosnowski's process to inflict a moral wound against old elites, which - as the press claimed - wanted to preserve their monopoly for patriotism, but in reality were revealed to be corrupted and morally putrid. Another symptom of this phenomenon was a quiet and discreet purge in the civil offices, performed as an element of fight with immorality. It went as far as the International Affairs Office and the vice-Chief of the Protocol von Mumm; his superior Count Basewitz resigned from office, apparently to take the post of a representatives in Athens. Although von Mumm was charged on the basis of Paragraph 175, it was a well-known fact that he was very critical of the national socialists, as he was open about it. On the other hand, Basewitz was related to the imperial family and was attempting to get close to the former leadership of SA and people close to Röhm. In this way, he wanted to link the Prussian elites with the SA leaders. He organized famous evening parties, where one could meet not only the members of the 
imperial household and the eminent representatives of Prussian monarchism, but also the most well-known members of SA. Among them were all those that lost their lives during the Night of the Long Knives. After Röhm was executed, these parties stopped taking place, although Basewitz continued his plan discretely. These seem to be the real reasons behind his removal from office (Archiwum Akt Nowych, sygn. 313/186-189).

It is estimated that during the existence of the Third Reich, about a hundred thousand homosexual men were put on the so-called „pink lists." Half of these people were executed, and between five to fifteen thousand men were sent to concentration camps, where they were marked with a sign of a pink triangle. It should be stressed that in German camps gay men belonged to the most inferior caste, and therefore often would not experience empathy from their fellow prisoners. They were allocated the hardest jobs and treated as deviants (Tritt, 2011, p.116). Admittedly, in theory, homosexual men were sent to concentration camps to be re-educated and not exterminated, yet the mortality rate among them at 55\% was very high (Tritt, 2011, p.116). This was the result, among other things, of the cruelty experienced by the inmates with the pink triangle from the SS officers. What is more, gay men were castrated and underwent treatments which constituted administration of high doses of testosterone (Tritt, 2011, p.117). The government also encouraged German citizens to turn in their gay neighbours and acquaintances. From the initiative of Henrich Himmler, on 16 October 1936 the Reich Central Office for the Combating of Sexuality and Abortion was founded (Tritt, 2011, p.116). Its basic task was to combat these aspects of social life which, according to the Nazi authorities, would affect the demographics of German society. When the aforementioned office was established, from 1937 onwards there was a large increase in arrests of homosexual men in Germany. When gay sexual workers were arrested, they were often forced to reveal the name of their clients (Tritt, 2011, p.116). Persecution of homosexual men continued until the end of the Third Reich. The end of the Second World War did not always mean freedom for imprisoned homosexual men. In allied- 
occupied Germany there were British and American lawyers who demanded that men sentenced to imprisonment based on Paragraph 175 should stay in prison till the end of their term. There were cases in which it was demanded that men who spent part of their term in a prison and part in a concentration camp should go back to prison after 1945 for the period of time they had spent in the camp. Until now it is unknown how many men served their term this way (Biedroń, 2012, p.50).

\section{THE RIGHTS OF GAY MEN IN THE BRD AND THE DDR TILL 1969}

The Federal Republic of Germany, as a legal and political inheritor of the German Reich, took over the whole historical legacy of the Paragraph 175. Yet, in the initial stages of this newly established German state, the provisions of this law were not changed. There is a number of reasons for this state of affairs. Firstly, the BRD faced the problem of reckoning with the Nazi past. It was not an easy task, as Hitler's totalitarian state incriminated the majority of German society. According to research done by Malte Herwig, a German journalist who for six years studied the NSDAP archives which had been opened in 1994, Germany after the Second World War underwent only a superficial denazification. Many West German politicians, including the members of CDU, were members of NSDAP before 1945. This led to a paradox where persons accused of war crimes were prosecuted by the ex-members of Hitler's party. It seems that even Konrad Adenauer, the Chancellor of Germany between 1949 and 1963, was not interested in a more profound denazification. He claimed: "if we keep looking, there is no way of knowing who we will end up with" (Kokot). In such a situation, it was hard to expect that the atonement for the Nazi crimes concerning sexual orientation would come to the fore, and similarly, a change or removal of Paragraph 175 did not seem to be a priority. Secondly, one cannot forget that West Germany of that period was socially conservative, and topics concerning sexuality were a taboo. The world of homosexual men constituted of secret meetings in hidden places, and therefore homosexuality was not rooted in a social space 
(Sigusch, 2010, p.8). Thirdly, one should also pay attention to the German legal tradition, where some provisions of the law are successfully incorporated in subsequent forms of German state, irrespectively of the political system of a given period. The provisions of Paragraph 175 and its derivatives applied throughout 123 years, similarly to the Reich Citizenship Law, which, established in 1913, was amended only in 1999. Finally, the BRD in the first years of its existence focused on gaining trust in the international arena, and on rebuilding the country which had been destroyed in the war.

Transformations in the social life of the BRD took place in 1960s in line with the social and cultural revolution in the countries of the Western Europe. Students' demonstrations in Germany had a special foundation. Young Germans were irritated by the fact that the so-called "great coalition" in the government of 1 December 1966, made of the Christian democratic CDU/CSU and social democratic SPD, was basically uncontrolled by a strong opposition in the Bundestag. They were apprehensive of authoritarian tendencies present in the BRD. The generation which will later lead to the protests of March 1968 in the Federal Republic of Germany felt stigmatised by the past and demanded for the persons previously linked to the Nazi regime to be removed from the political and public life. This generation felt that denazification in West Germany did not really happen, as several years before Hans Gobke - the co-creator of the Nuremberg Laws - was an éminence grise in Konrad Adenauer's government on a position of the Secretary of the State, while Theodor Oberländer - an ex-general in Wehrmacht - was the leader of Intelligence Services. A social upheaval was caused by the fatal shooting of Benn Ohnesorg, who demonstrated against a visit of Reza Pahlavi, the Shah of Iran, in the BRD (Tomczak). This event led thousands of students to the streets and changed the social and political situation of the Federal Republic of Germany, as it led to liberalization, and not only in the spheres of society and culture. The events of 1968 in the BRD resulted a creation in leftist pacifists and ecologist movements, from which the future leaders of the Green Party originated. The events of March 1968 in the BRD definitely showed that the young generation of Germans wanted a political and social change and rejected the social conservatism of CDU and CSU, paving the way for 
victory of the Social Democratic Party of Germany (SPD) in 1969 elections. The same year brought about changes in the Criminal Code and the Federal Republic of Germany bid farewell to the post-Nazi Paragraph 175, preserving only the age of consent for homosexual acts to be 21 years old (Jartyś, 2015, p. 184).

It is difficult to assess to what extent the removal of Paragraph 175 from the Criminal Code of the BRD was influenced by the fact that the DDR, where Paragraph 175 had applied since the Weimer Republic, removed it in 1967, preserving only the age of consent for homosexual acts to be 18 years of age (Biedroń, 2012, p.51). Application of Paragraph 175 in both German states till 1967 and 1969 respectively caused an enormous amount of social harm. Admittedly, in the DDR the provisions of Paragraph 175 were used much more rarely to prosecute gay men than in the BRD, yet until the removal of this law, around 4000 people were prosecuted for indecent behaviour in the DDR (Hoffschidt, 2016, p.27). When it comes to the BRD, which applied the Nazi's version of Paragraph 175 till 1969, the number of the prosecuted is the staggering 60663 people (Hoffschidt, 2016, p.27). It should be remembered that those who had been sentenced according to this law felt stigmatised in their workplaces and in their neighbourhoods, and an annotation about their criminal past in their files made further employment difficult. One should not forget that the revelation of homosexuality, combined with a criminal sentence, very often destroyed the family ties as well.

\section{A ROAD TO LIBERALISATION}

Since the beginning of the 1970s West German society underwent a slow social transformation in its attitudes towards homosexuality. In 1973 in the BRD the age of consent for homosexual acts was changed to be 18 years old. Perhaps such a decision made by the West German government of the time was influenced by the fact that the same year the American Psychiatric Society removed homosexuality from the list of mental illnesses (Dąbrowski, Niemiec, 2003, p.10). Finally, the Federal Republic of Germany removed any remnants of Paragraph 175 from its 
legislation in 1994 when the consent age for heterosexual and homosexual relations became the same (Jartyś, 2015, p. 184). This took place four years after the unification of Germany and three years after the World Health Organisation removed homosexuality from its International Classification of Diseases (Dąbrowski, Niemiec 2003, p. 10). Yet, between the unification of the previous BRD and DDR on 3 December 1990 until the aforementioned removal of the laws in 1994, Paragraph 175 was the basis for the prosecution of 68808 people (Hoffschidt, 2016, p. 27).

\section{POLITICAL, LEGAL AND SOCIAL TRANSFORMATIONS AFTER THE UNIFICATION OF GERMANY}

Irrespectively of the infamous past related to the application of Paragraph 175 in Germany, it has to be admitted that after 1994 German society underwent a fast change in mentality when it comes to their attitude to non-heterosexual persons. This was furthered by the following aspects: firstly, in 1994 the Commission for Fundamental Rights and Commission for Internal Affairs in the European Parliament have proclaimed a Report on the equality of LGBT people in the European Union, which presented the issues of discrimination against homosexual persons in the member countries. The results of this work were the provisions of the Article 13 of the Amsterdam Treaty, and subsequently the directive of the European Council against discrimination in the workplace, issued in 2000 (Jartyś, 2015, p.183). Also, one should not forget about the provisions of the Charter of the Fundamental Rights of the European Union, decreed in Nice in 2000 (Hambura, Muszyński, 2001, p.112), which later became an integral part of the Lisbon Treaty. In spite of its difficult past connected with lack of respect for the rights of the homosexuals, the Federal Republic of Germany after 1994 was able to change the attitudes of German society very quickly, and in this way they rooted their values in the European values of human rights. These rights were incorporated in the German legislation and in 2001 Bundestag proclaimed a law allowing homosexual civil partnerships in Germany (Szukalski, 2011, p. 173). Furthermore, in 2012 a group of 13 parliamentarians from CDU, which 
is a party founded on Christian values, suggested that persons in civil partnerships should be allowed to file and pay taxes jointly. It was a surprise for the general public, especially considering the fact that in this group included Kristina Schröder, the Ministry of Family, known for her conservative outlook. She explained her attitude in the following way: "in lesbian and gay life partnerships, people take lasting responsibility for one another and thus they live according to conservative values" (CDU wspiera...). A change in social mentality happened so fast that German society accepts politicians who openly admit to homosexual orientation. Klaus Wowereit from SPD, who ran for mayor of Berlin in 2001, in one of his electoral meetings said: "I am gay and that is fine" (Berlin Yogyakarta, 2009, p.11); he won the elections and held the office until 2014. Similarly, Guido Westerwelle, the former vice-Chancellor and Minister of Internal Affairs in the Christian democratic government of Angel Merkel did not hide is homosexual orientation. Social and legal changes in relation to homosexuality made it necessary to accept leftist slogans on rights of minorities by Christian democratic parties, CDU and CSU, which has been generally achieved, and the rights of the homosexuals in the BRD slowly stopped being used as a bone of contention in political and social discourse. Even in a conservative and anti-immigrant Alternative for Germany (AfD), founded in 2014, the issues linked to sexual orientation do not cause any controversies. An example of this fact is Alicia Weidel's political career; her homosexuality is well known (Yorulmaz) and, what is even more interesting in the context of AfD, she is in a relationship with Sarah Bossard from Sri Lanka (Janssen, Szczerbiak).

A transformation after 1994 of German legislation in terms of the rights of homosexual persons and the re-evaluation of the mentality of German society even led to a certain paradox, as the parliamentarians and citizens of a state in which only twenty years earlier people were prosecuted on the basis of a Nazi version of Paragraph 175 came to Warsaw to participate in equality parades and marches to defend the rights of Polish gay citizens during the rule of Law and Justice, as it was the case when in 2006 Bundestag members Claudia Roth and Renate Künast from the Green Party. It is even more blatantly paradoxical if we consider the fact that these parliamentarians came to the state in which penalisation of 
homosexual acts was abandoned as early as 1932. Admittedly, a change in mentality has not been as fast in Poland as it has been in Germany in the recent years. It is also paradoxical that Poland, as well as Bulgaria, Lithuania, Latvia, Romania and Slovakia, is now one of the six member states of the European Union in which same-sex civil partnerships were not regulated, while in the Federal Republic of Germany the Parliament including SPD, CDU and the Green Party - voted in favour of homosexual marriage on 30 June 2017, becoming a model of how human rights of LGBT people should be respected (Gdzie uznaje się prawa LGBT).

It has to be stressed, however, that a discussion and the subsequent voting for the law accepting homosexual marriage took place just before the Bundestag elections, in which Angela Merkel and her Christian democratic CDU and Bavarian CSU stood for another term in the Chancellor office. The issue of legal marriage equality become a topic for discussion between these two parties. For instance, Wolfgang Schäuble, Minister of Finance from CDU, called for signing a same-sex marriage act, claiming that if his party is to maintain its image of a mass party, it has to keep up with the fast-changing society. An opposite approach was exemplified by Horst Seehofer from the Bavarian CSU in the coalition with CDU. The opposition to this act reminded the general public that not so long ago Angela Merkel herself was against these changes. As a result of this discussion, the party discipline in this voting was suspended in CDU, therefore its members could vote in agreement with their own personal opinions. It should be stressed that liberalisation of the same-sex marriage law was supported in the surveys by $64 \%$ of CDU electorate (Spór o homoseksualistów). The same-sex marriage act was proclaimed by the Bundestag, although Angela Merkel herself voted against it (Bundestag przyznał...). Her decision could be a result of two factors. Firstly, Angela Merkel is a daughter of an Evangelical minister, so probably she was brought up in traditional, more conservative values. Secondly, her vote against the act in question could have been a nod towards more conservative CDU electorate. It is difficult to assess to what extent the same-sex act signed by Angela Merkel's party helped them win the parliamentary elections on 17 September 2017. Yet, social transformations within CDU led to an obliteration of an ideological conflict between the German Christian democ- 
racy and the left. As a result, this years' electoral results are the weakest for SPD since 1949, as this party gained only $20,5 \%$ votes, while in the last four years it ruled the Federal Republic of Germany in coalition with Christian democratic parties CDU and CSU (Niemcy oficjalne wyniki wyborów).

\section{CONCLUSIONS}

The Federal Republic of Germany introducing the civil partnership and same-sex marriage acts into its legislation is obviously trying to obliterate those years between 1949 and 1994 in which Paragraph 175 was in effect. It is, however, an undisputable fact that this state, which is publicly perceived as a democratic one and a co-founder of the European Union, in the first twenty years of its existence has been using an unamended, Nazi version of legal provisions concerning human rights, and prosecuted its citizens based such a law. Even though currently the Federal Republic of Germany constitutes a model state in which the rights and freedoms of citizens, including the non-heterosexual ones, are respected, it has not fully atoned for its past in this respect. The question of moral rehabilitation of people sentenced in the past for homosexual acts on the basis of Paragraph 175 remains open. On 8 May 1985 the President of the BRD Richard von Weizsäker spoke about the suffering inflicted on homosexuals by the Nazis (Sigmund 205:182). It took many years to full rehabilitate the homosexual victims of Nazi authorities, as it took place in 2002 (Berlin Yogyakarta, 2009, p.7). However, there remains the issue of those people who were prosecuted and sentenced according to Paragraph 175 after 1949. Until now, the Bundestag has only expressed their regrets, while the Bundesrat called to introduce laws which would invalidate the sentences made according to Paragraph 175 (Burgi, Wolff, 2016, p.53). The government of the Federal Republic of Germany started drafting such a law in 2016. As Minister of Justice, Heiko Maasa, assured the public, this law would allow an individual right to compensation and an easy procedure to receive one. The amount of compensation would be established individually, on the basis of, among other things, the length of the prison 
term that homosexual persons sentenced on the basis of Paragraph 175 had to serve (Niemieccy geje...). German authorities plan to assign at least 30 million Euro for compensation to about five thousand gay men still alive in Germany who had been persecuted after the Second World War (Niemcy wypłaca...). There is a chance, then, that the Federal Republic of Germany will atone, at least symbolically, for using a Nazi legislation against homosexual men in ways which were in opposition to the European standards of human rights.

\section{BIBLIOGRAPHY:}

Archiwum Akt Nowych, Zbiór Ambasada Rzeczypospolitej Polskiej w Berlinie sygn. 313/186-189.

Berlin Yogyakarta. (2009). Od hitlerowskiego terroru wobec osób homoseksualnych do praw człowieka dzisiaj, Warszawa: Kampania Przeciw Homofobii.

Biedroń, R. (2016). Nazistowskie prześladowania osób homoseksualnych. In: K. Remin (ed.). Różowe trójkąty, zbrodnie nazistów na osobach homoseksualnych $w$ kontekście edukacji antydyskryminacyjnej (pp. 14-54). Warszawa: Kampania Przeciw Homofobii.

Bundestag przyznał homoseksualistom prawo do małżeństwa. Downloaded from: http:// www.newsweek.pl/swiat/niemcy--spor-o-homoseksualistow-dzieli-koalicje-rzadowa, 102064,1,1.html.

Bundestag przyznał homoseksualistom prawo do małżeństwa. Merkel głosowała przeciw. Downloaded from: http://www.polsatnews.pl/wiadomosc/2017-06-30/bundestagprzyznal-homoseksualistom-prawo-do-malzenstwa-merkel-glosowala-przeciwko.

Burgi, M., Wolff, D. (2016). Rehabilitierung der nach $\$ 175$ StGB verurteilten homosexuellen Männer: Auftrag, Optionen und verfassungsrechtlicher Rahmen, Antidiskriminierungstelle des Bundes, Berlin: Nomos.

CDU wspiera homoseksualistów. Downloaded from: http://wyborcza. pl/1,76842,12271809,CDU_wspiera_homoseksualistow.html

Dąbrowski, L., Niemiec, S. (eds.). (2003). Prawa mniejszości seksualnych-prawami człowieka, Seminarium marzec 2003, Biblioteczka Pełnomocnika Rządu ds. Równego Traktowania Kobiet i Mężczyzn, 5 (9).

Dippold, M., Leisteter, S. (2013). Paragraph 175. Verbotene Liebe im 20. Jahrhundert Ein Schulbuchkapitel für den Geschichtsunterricht an Gymnasien (empfohlen für die Sekundarstufe I, Klasse 10), Lepzig: Universität Leipzig. 
Geschischte Projekte. Downloaded from: https://www.unioldenburg.de/fileadmin/ user_upload/geschichte/projekte/ol.verfolgungsszenarien/download/Rosa_Winkelscript.pdf.

Grudgesetz für die Bundesrüepublik Deutschland (2004), Berlin: Bundeszentrale für politische Bildung.

Gdzie uznaje się prawa osób LGBT? Mapa Europy. Downloaded from: http://www.newsweek.pl/swiat/spoleczenstwo/teczowa-europa-gdzie-uznaje-sie-malzenstwa-lgbtmapa,artykuly,412466,1.html.

Hambura S., Muszyński S., (2001) Karta Praw Podstawowych Unii Europejskiej z komentarzem, Bielsko- Biała: Studio Sto.

Hoffschidt, R. (2016). Kriminalisierung und Verfolgung homosexueller Handlungen unter Männern durch Justiz und Polizei in der Bundesrepublik Deutschland von der Nachkriegszeit bis 1994, Hannover.

Janssen M, Szczerbiak A., Kim jest Alicie Weidel? Lesbijka w partii homofobów. Downloaded from: http://www.polityka.pl/tygodnikpolityka/swiat/1721576,1,kim-jestalice-weidel-lesbijka-w-partii-homofobow.read

Jartyś, J. (2015). Wkład Polski do procesu umiędzynarodowienia praw osób Lesbian, Gay, Bisexual, Transgender (LGBT) po akcesji Polski do Unii Europejskiej. In: L. Wojnicz, D. Rdzanek, M. Potkańska (eds.). W poszukiwaniu finalite politique Unii Europejskiej. Aspekty teoretyczne i praktyczne (pp. 183-197). Szczecin - Warszawa: Instytut Politologii i Europeistyki Uniwersytetu Szczecińskiego, Instytut Europeistyki Uniwersytetu Warszawskiego.

Kokot, M. Jak RFN przez długie lata krył nazistów w swoich rządach. Downloaded from: http://wyborcza.pl/1,76842,13867398,Jak_RFN_przez_dlugie_lata_kryl_ nazistow_w_swoich_rzadach_html (07/10/2017)

Niemieccy geje z odszkodowaniami za prześladowanie. Downloaded from: https://parezja. $\mathrm{pl} /$ niemieccy-geje-odszkodowaniami-przesladowanie.

Niemcy, oficjalne wyniki wyborów. Downloaded from: https://www.tvn24.pl/wiadomoscize-swiata,2/niemcy-oficjalne-wyniki-wyborow-wszyscy-zwyciezcy-stracili,775700. html.

Niemcy wypłaca odszkodowania homoseksualistom. Downloaded from: http://www.rp. pl/Swiat/303229864-Niemcy-wyplaca-odszkodowania-homoseksualistom.html\#ap-1 Spór o homoseksualistów dzieli koalicję. Downloaded from: http://www.newsweek.pl/ swiat/niemcy--spor-o-homoseksualistow-dzieli-koalicje-rzadowa,102064,1,1.html. Sigmund, A.M. (2015). Sex w III Rzeszy, Warszawa: Bellona.

SPDqueer Berlin. Downloaded from http://www.spdqueer-berlin.de/ns-verfolgung. Sigusch, V. (2010). Homosexuelle zwischen Verfolgung und Emanzipation. Aus Politik und Zeitgeschichte, Homosexualität 15-16. 
Szukalski, P. (2011). Rejestrowane związki tej samej płci we współczesnej Europie. Dysfunkcje Rodziny. Rocznik Socjologii Rodziny, XXI, pp.169-184.

Tomczak, S. Rok 1968 w Republice Federalnej Niemiec i jego skutki. Downloaded from: https://historia.org.pl/2013/08/10/rok-1968-w-republice-federalnej-niemiec-i-jegoskutki/

Tritt, J. (2011). Czy odmienny i wykluczony może zostać odzyskanym? Dyskurs poświęcony homoseksualnym mężczyznom. Roczniki Pomorskiej Akademii Medycznej w Szczecinie, 57(2), pp.110-123.

Yorulmaz, A. (2017). Die AfD hat ein Problem mit Homosexuellen. Downloaded from: http://www.zeit.de/politik/deutschland/2017-09/alternative-fuer-deutschland-aliceweidel-homosexualitaet

Verfolgung von Lesben und Schwulen im Nationalsozialismus Ein Kunstdenkmal in München. (2017), München: Landeshaupstadt Munchen.

Vertrag zwischen der Bundesrepublik Deutschland und der Deutschen Demokratischen Republik über die Herstellung der Einheit Deutschlands (Einigungsvertrag), https:// www.gesetze-im-internet.de/einigvtr/EinigVtr.pdf (07/10/2017) 